ORIGINAL ARTICLE

\title{
Characteristics of breast milk and serology of women donating breast milk to a milk bank
}

\author{
P C Lindemann, I Foshaugen, R Lindemann
}

Arch Dis Child Fetal Neonatal Ed 2004;89:F440-F441. doi: 10.1136/adc.2003.046656

See end of article for authors' affiliations

.....................

Correspondence to: Dr R Lindemann,

Department of Paediatrics, Ullevål University Hospital, NO-0407 Oslo, Norway; roli@uus.no

Accepted

24 December 2003
Objective: Breast milk is the most important nutrient to all newborn babies. If the mother's milk production is insufficient, it is important to provide donor breast milk without reduction of its immunologic and antimicrobial properties. Early use of breast milk to preterm infants has shown a reduced incidence of necrotising enterocolitis, a faster tolerance of enteral feeding, and a reduced need of parenteral nutrition. It is important to have milk from a CMV-lgG negative donor to VLBW infants considered immunocompromised.

Methods: Between January $1^{\text {st }}$ and December $31^{\text {st }} 2001$, 69 women delivered 1.973 litres (mean 28.6 litres/woman/year). 73\% had college education, were primipara, and with a mean age of 30.7 years. Those who smoked, used alcohol or any medications were refused as donors. They started to deliver approximately 7 weeks after having given birth and continued for a mean of 4 months. Each milk sample was tested for bacterial growth. Every donor was screened for HIV, CMV-lgG and hepatitis B/C before donating milk and thereafter every third month.

Results: $62.3 \%$ was CMV-lgG positive. Samples containing staphylococcus aureus, klebsialla-, enterobacter- and serratia-species or E. coli, and all samples containing $>10^{4} \mathrm{cfu} / \mathrm{ml}$ were pasteurised. Overall, only $10.5 \%$ of the samples were pasteurised.

Conclusion: It is possible and important to provide VLBW babies with fresh frozen unpasteurised CMV-lgG negative breast milk until their own mothers' milk production is sufficient.
$\mathrm{H}$ uman breast milk is considered to be the most important nutrient for newborn babies, especially preterm ones. ${ }^{1-6}$ If the mother does not produce sufficient milk, fresh frozen unpasteurised milk from a milk bank should be available to all ill neonates until the mother's own production is established.

Very low birthweight (VLBW) infants and those with a gestational age of less than 32 weeks are considered to be immunocompromised with a risk of developing serious infections..$^{7-10}$ Bank milk should therefore be free of pathogenic bacteria and generally have a bacterial content of less than $10^{4}$ colony forming units $/ \mathrm{ml}$. The donors should test negative to cytomegalovirus (CMV), HIV, and hepatitis B and $\mathrm{C}$, in order to prevent a serious viral infection.

Early use of breast milk for preterm infants has resulted in a reduced incidence of necrotising enterocolitis, ${ }^{11-15}$ faster tolerance of enteral feeding, ${ }^{1-5}$ and thus a reduced need for parenteral nutrition.

This study was carried out to investigate the characteristics of the milk and the serological status of mothers donating breast milk to a milk bank in Oslo, Norway.

\section{MATERIAL AND METHODS}

Between 1 January and 31 December 2001, the serological status of donors and the characteristics of the milk donated to the milk bank at Ulleval University Hospital were studied. Women who smoked or used alcohol or any drugs were refused as donors.

The women were carefully instructed in hygienic procedures and how to clean the equipment. A breast milk pump and single use paper towels were provided. The women were paid NOK 135/litre donated tax-free (equal to $€ 16 / £ 10 / \$ 19$ ).

Most of the donors had received a college education (73\%) and were primiparous, with a mean age of 33.8 years. Table 1 shows their basic details.

Most of the women delivered at term, but some had preterm babies. The median birth weight of the children was $3360 \mathrm{~g}$ (range 630-4500), the smallest with a gestational age of 27 weeks, showing that some mothers expressed more milk than their preterm infant needed.

Every donor had a screening test for HIV during her pregnancy, before donating milk and then every third month, in addition to tests for CMV and hepatitis B/C. Each milk sample was tested for bacterial growth.

Samples containing Staphylococcus aureus, Klebsiella-, Enterobacter-, Serratia-species, or Escherichia coli were not accepted as "fresh frozen" and were thus pasteurised. All samples with a bacterial count of more than $10^{4}$ colony forming units $/ \mathrm{ml}$ were pasteurised $\left(56^{\circ} \mathrm{C}\right.$ for 30 minutes). All the pasteurised samples were retested for bacterial growth and only accepted when germ-free.

\section{RESULTS}

The women started to donate milk about seven weeks (median) after having given birth (range $1-21$ weeks) and continued for a mean of four months (range $<1-13$ ). During the study period, the women delivered a total of 1.973 litres breast milk (mean 28.6 litres/woman/year). The total amount of milk donated was 2.673 litres, with a mean amount of 38.7 litres/woman. The highest amount from one woman was 392 litres. Two thirds of the mothers were CMV IgG positive $(62 \%)$. None tested positive for HIV or hepatitis B or C.

Samples containing $S$ aureus, Klebsiella species, Enterobacter species, E coli, or other bacteria considered "pathological" for a newborn or VLBW child were not accepted as "fresh frozen milk" and were thus pasteurised. Samples with any bacterial flora containing more than $10^{4}$ colony forming units $/ \mathrm{ml}$ were also pasteurised, regardless of type of bacteria $(2.5 \%$ of all the samples). Overall, only $10.5 \%$ of the total amount of milk was pasteurised. Table 2 presents the bacterial content and type of bacteria in the milk samples.

Milk that had to be pasteurised was used for ill full term or newborn infants undergoing surgery or babies whose mothers refused to use milk formula during the first few days.

None of the infants acquired $S$ aureus infections from bank milk as all samples containing any of this bacterium were pasteurised. Infants assumed to be immunocompromised $(\leqslant 1500 \mathrm{~g} / \leqslant 32$ weeks) were fed CMV IgG negative bank milk. We did not test the infant's own mother for her CMV status. She usually expressed more milk than her baby tolerated, and milk samples were therefore kept frozen. 
Table 1 Relevant details of 69 women who donated breast milk during the one year study period

\begin{tabular}{|c|c|c|c|}
\hline & & Mean (SD) & Median (range) \\
\hline Age (years) & & $33.8(4.9)$ & $30(21-45)$ \\
\hline Number of pregnancies & & $1.74(0.98)$ & $1(1-5)$ \\
\hline $\begin{array}{l}\text { When started to donate milk } \\
\text { (weeks) }\end{array}$ & & $7.35(4.4)$ & $7(1-21)$ \\
\hline $\begin{array}{l}\text { How long did they donate milk } \\
\text { (months) }\end{array}$ & & $3.87(2.96)$ & $3(<1-13)$ \\
\hline Amount of milk donated (litre) & & $28.7(61.3)$ & $18.4(2.4-392)$ \\
\hline College/university & $72.5 \%$ & & \\
\hline High school (12 years) & $15.9 \%$ & & \\
\hline Compulsory nine year schooling & $11.5 \%$ & & \\
\hline
\end{tabular}

Table 2 Type of bacteria and occurrence in milk samples

\begin{tabular}{ll}
\hline Type of bacterium & Occurrence (\%) \\
\hline Staphylococcus epidermidis & 85.0 \\
Staphylococcus aureus & 13.1 \\
a Haemolytic streptococcus & 10.6 \\
Acinetobacter species & 5.4 \\
Serratia species & 2.5 \\
Klebsiella species & 2.0 \\
Enterobacter species & 1.8 \\
Bacillaceae species & 1.5 \\
Escherichia coli & 0.45 \\
Others & 1.0 \\
\hline
\end{tabular}

In some samples, two or more bacteria were detected. The types presented in italics were pasteurised regardless of number of colony forming units.

\section{DISCUSSION}

Human breast milk is considered to be the most important nutrient for newborn babies especially VLBW ones. Owing to its anti-infectious effect and immunoglobulin content, breast milk is preferable to preterm milk formulas..$^{1-6}$ If a mother has insufficient milk, banked human milk (preferably fresh frozen and unpasteurised) should be made available until her own milk production is established.

VLBW infants are considered to be immune incompetent, with an increased risk of developing serious infections..$^{7-10}$ The use of intravenous IgG has, however, been debated. ${ }^{16}{ }^{17}$ The content of immunoglobulins (IgA) in breast milk is therefore of great importance for the protection of the immunocompromised VLBW infants. ${ }^{6}$

Bank milk should therefore contain no bacteria that may cause infection or $\geqslant 10^{4}$ colony forming units $/ \mathrm{ml}$ of any bacteria. ${ }^{18}$ Milk from a milk bank should also be free of infectious viruses, such as CMV, hepatitis B/C, and HIV. The donor should have a negative serum screen for these viruses before starting to donate milk.

Necrotising enterocolitis is a serious disease that can affect the VLBW infant. It has been shown that breast milk protects against the development of this disease, ${ }^{9-13}$ supporting the importance of the early introduction of breast milk to preterm infants. ${ }^{1-5}$

Even though the fetus swallows amniotic fluid, the intestine is not prepared for enteral feeding. It has, however, been shown that early enteral feeding, even small amounts (trophic feeding), improves gut motility and thereby the tolerance of enteral feeding in the VLBW infant. ${ }^{1-6}$

Early tolerance of enteral feeds means that the need for parenteral nutrition is reduced. As parenteral feeding is associated with, among other things, increased risk of infections, liver impairment, and thrombocytopenia, ${ }^{18}{ }^{19}$ early introduction of breast milk will thus reduce these complications.

To be able to provide fresh frozen human breast milk to every VLBW infant, it is important to maintain a milk bank and thus the possibility to provide the optimum substitute for mother's own milk.

It has been debated whether fresh frozen milk donated to a milk bank from a CMV IgG negative mother is superior to the milk from the infant's own mother, not knowing or before knowing her CMV status. ${ }^{20}{ }^{21}$ Should a CMV positive mother be allowed to breast feed her own child? Or should her milk be kept frozen for three or more days or even pasteurised? It is important to look out for signs of CMV infection in VLBW infants fed their own mother's milk without knowing her CMV status. If any of our infants develop severe pulmonary problems, a sample of their urine is tested for CMV. If the test is positive, the infection is more likely to come from its mother than from the banked milk.

The use of fresh frozen unpasteurised bank milk promotes enteric feeding of live microbial supplements (probiotics) which may provide benefit and help to prevent diseases such as necrotising enterocolitis. ${ }^{22}$

This study shows that our milk bank is run safely to provide fresh frozen unpasteurised, CMV negative donor breast milk to every VLBW neonate $(<1500 \mathrm{~g})$, providing optimal growth and development of the infant.

\section{Authors' affiliations}

P C Lindemann, R Lindemann, Neonatal Intensive Care Unit, Department of Paediatrics, Ullevål University Hospital, NO-0407 Oslo, Norway I Foshaugen, R Lindemann, The Milk Bank, Ullevål University Hospital

\section{REFERENCES}

1 Armand M, Hamosh M, Mehta NR, et al. Effect of human milk or formula on gastric function and fat digestion in the premature infant. Pediatr Res 1996:40:429-37.

2 McClure RJ, Newell SJ. Randomised controlled trial of trophic feeding and gut motility. Arch Dis Child Fetal Neonatal Ed 1999;80:F54-8.

3 McClure RJ, Newell SJ. Randomised controlled study of clinical outcome following trophic feeding. Arch Dis Child Fetal Neonatal Ed 2000;82:F29-33.

4 Rojahn A, Lindgren CG. Enteral feeding in infants $<1250 \mathrm{~g}$ starting within $24 \mathrm{~h}$ post-partum. Eur J Pediatr 2001;160:629-32.

5 Simpson C, Schanler RJ, Lau C. Early introduction of oral feeding in preterm infants. Pediatrics 2002;1 10:517-22.

6 Gross SJ, Buckley RH, Wakil SS, et al. Elevated IgA concentration in milk produced by mothers delivered of preterm infants. J Pediatr 1981;99:389-93.

7 Whitelaw A, Parkin J. Development of immunity. Br Med Bull 1988;44:1037-51.

8 Stoll BJ, Hansen N, Fanaroff AA, et al. Late-onset sepsis in very low birth weight neonates: the experience of the NICHD neonatal research network. weight neonates: the experience
Pediatrics 2002; 110:285-91

9 Schanler RJ. Human milk for preterm infants: nutritional and immune factors. Semin Perinatol 1989;13:69-77.

10 Howie PW, Forsyth JS, Ogston SA, et al. Protective effect of breast feeding against infection. BMJ 1990;300:11-16.

11 Lucas A, Cole TJ. Breast milk and neonatal necrotising enterocolitis. Lancet 1990;336:1519-23.

12 McGuire W, Anthony MY. Donor human milk versus formula for preventing necrotising enterocolitis in preterm infants: systematic review. Arch Dis Child Fetal Neonatal Ed 2003;88:F1 1-14.

13 Dvorak B, Halpern MD, Holubec $\mathrm{H}$, et al. Maternal milk reduces severity of necrotizing enterocolitis and increases intestinal IL-10 in a neonatal rat modell. Pediatr Res 2003;53:426-33.

14 Berseth CL, Bisquera JA, Paje VU. Prolonging small feeding volumes early in life decreases the incidence of necrotizing enterocolitis in very low birth weight infants. Pediatrics 2003;111:529-34.

15 Kligman RM. The relationship of neonatal feeding practices and the pathogenesis and prevention of necrotizing enterocolitis. Pediatrics 2003;111:671-2.

16 Sandberg K, Fasth A, Berger A, et al. Preterm infants with low immunoglobulin $G$ levels have increased risk of neonatal sepsis but do not benefit from prophylactic immunoglobulin G. J Pediatr 2000;137:623-8.

17 Ohlsson A, Lacy JB. Intravenous immunoglobulin for preventing infection in preterm and/or low-birth-weight infants. Cochrane Database Syst Rev 2001;(2):CD000361.

18 Simmer K. Neonatology for the generalist. Human milk banks and evidencebased medicine. J Paediatr Child Health 2000;36:182-3.

19 Yu VYH. Parenteral nutrition. In: Rennie JM, Roberton NRC, eds. Textbook of neonatology, 3rd ed. London: Churchill Livingstone, 1999:349-58.

20 Hamprecht K, Maschmann J, Vochem D, et al. Epidemiology of transmission of cytomegalovirus from mother to preterm infant by breastfeeding. Lancet 2001;357:513-18.

21 Bryant P, Morley C, Garland S, et al. Cytomegalovirus transmission from breast milk in premature babies: does it matter? Arch Dis Child Fetal Neonatal Ed 2002;87:F75-7.

22 Millar M, Wilks M, Costeloe K. Probiotics for preterm infants? Arch Dis Child Fetal Neonatal Ed 2003;88:F354-8. 